\title{
Pembelajaran Berbasis Inkuiri dengan Model The 5 E Learning Cycle dapat Meningkatkan Keaktifan Belajar dan Hasil Belajar Siswa
}

\author{
Rudi Purnomo ${ }^{1}$ \\ 1Pendidikan Dasar-Universitas Negeri Malang
}

\section{INFO ARTIKEL}

\section{Riwayat Artikel:}

Diterima: 7 juni 2019

Disetujui: 4 Oktober 2019

\section{Kata kunci:}

Inkuiri

The 5E learning cycle

Keaktifan belajar

Hasil belajar

\begin{abstract}
ABSTRAK
Abstract: Learning inquiry with The $5 \mathrm{E}$ Learning Cycle use increase active and learning outcomes. Indicates that the students tend to be passive and less active. Students' activeness is determined from the data on the courage to ask question, to express opinion, and to argue the idea during learning. The learning result includes some aspects such as learning skill, psychomotoric skill, and cognitive skill, which all of them come from the evaluation (test) over students. Data collection methods are the writing test for students, the assessment of learning skill and psychomotoric skill from observation sheet, and questionnaire

Abstrak: Pembelajaran inkuiri dengan model The 5E Learning Cycle dapat digunakan meningkatkan keaktifan belajar dan hasil belajar siswa. Tujuan dari pembelajaran ini agar siswa tidak cenderung pasif dan kurang aktif dalam belajar, juga siswa tidak mempunyai kecenderungan pada hafalanhafalan saja. Keaktifan siswa diperoleh dari data keterlibatan mereka dalam keberanian bertanya, keberanian mengemukakan pendapat, dan keberanian mempertanyakan gagasan saat pembelajaran. Hasil belajar meliputi aspek keterampilan belajar, aspek psikomotorik dan aspek kognitif yang dipeoleh dari evaluasi (tes) kepada siswa.
\end{abstract}

\author{
Alamat Korespondensi: \\ Rudi Purnomo \\ Pendidikan Dasar \\ Pascasarjana Universitas Negeri Malang \\ Jalan Semarang 5, Malang 65154 \\ E-mail: purnomorudis@gmail.com
}

Hasil belajar fisika siswa kelas VII-E SMP Negeri 1 Singosari juga rendah. Hal ini ditandai dengan nilai ratarata hasil ulangan terakhir tentang perubahan kalor terhadap perubahan wujud zat yang dicapai siswa pada semester gasal tahun ajaran 2009-2010 adalah 66,77 dengan ketuntasan klasikal 60\%. Nilai ulangan KD tersebut masih jauh dari harapan, karena Kriteria Ketuntasan Minimal (KKM) yang ditetapkan sebesar 75, dengan criteria keberhasilan proses belajar minimal 85\% siswa tuntas. Nilai ulangan dan ketuntasan klasikal yang diperoleh siswa kelas VII-E tersebut mengindikasikan bahwa hasil belajar siswa masih rendah.

Rendahnya keaktifan belajar siswa dan hasil belajar siswa tersebut disebabkan model pembelajarannya sangat kurang tepat, karena guru hanya meberikan pembelajaran dengan model ceramah saja yaitu siswa hanya mendengar, mencatat saja, dan hanya menunggu apa yang akan diberikan oleh guru (Sanjaya, 2008). Keterampilan belajar yang dimiliki siswa sangat rendah karena dalam proses pembelajaran siswa jarang melakukan percobaan, peralatannya kurang lengkap dan keterbatasan waktu untuk melakukan percobaan. Perkembangan kognitif sebagian besar bergantung kepada seberapa aktif siswa memanipulasi dan berinteraksi dengan lingkungan. Perkembangan kognitif bukan merupakan akumulasi dari sekeping informasi terpisah, namun lebih merupakan pengkonstruksian oleh siswa untuk memahami lingkungan.

Guru hendaknya menyadari tentang pentingnya menumbuhkan keaktifan dan hasil belajar siswa dalam proses pembelajaran. Salah satu strategi pembelajaran yang berpotensi memberdayakan keaktifan belajar adalah strategi pembelajaran berbasis inkuiri (Wartini, Hadi al-asy'ari, \& Multahada, 2018). Secara umum strategi pembelajaran berbasis inkuiri ini, mengutamakan keaktifan belajar untuk memperoleh pengetahuan, 
dan salah satu tujuannya adalah agar para siswa memiliki keaktifan bekerja layaknya seorang ilmuwan. Pembelajaran berbasis Inkuiri yang di padu dengan model the 5E Learning Cycle siswa belajar dapat memecahkan masalah, berpikir kritis dan kreatif. Model siklus belajar (The 5E Learning Cycle), dalam setiap tahapan pembelajaran siswa terlibat secara aktif dalam proses pencarian pengetahuan/konsep, yang terdiri dari tahapan pembelajaran tersebut menurut (Bybee, 1989; Yuliati, 2008) antara lain Engagement (pendahuluan), Exploration (eksplorasi), Eksplanation (penjelasan), Elaboration (elaborasi), dan Evaluation (evaluasi). Hal ini disebabkan setiap tahap dalam siklus belajar dirancang agar siswa terlibat secara aktif dalam proses pengetahuan dan keterampilan.

Menurut Lorsbach dalam (Dasna, 2006) bahwa penerapan pembelajaran inkuiri dengan model siklus belajar lima tahap (The $5 E$ Learning Cycle) memiliki beberapa kelebihan yaitu: 1) Siswa belajar secara aktif. Siswa mempelajari materi secara bermakna dengan bekerja dan berfikir. Pengetahuan dikonstruksi dari pengalaman siswa, 2) Informasi baru dikaitkan dengan skema yang telah dimiliki siswa. Informasi baru yang dimiliki siswa berasal dari interprestasi individu, 3) Orientasi pembelajaran adalah investigasi dan penemuan yang merupakan pemecahan masalah.

Pada tahap Engagement bertujuan mempersiapkan diri siswa agar terkondisi dalam menempuh tahap berikutnya dengan jalan mengeksplorasi pengetahuan awal dan ide mereka serta untuk mengetahui kemungkinan terjadinya miskonsepsi pada pembelajaran sebelumnya. Tahap Exploration, siswa diberi kesempatan untuk bekerja sama dalam kelompok-kelompok kecil tanpa pengajaran langsung dari guru untuk menguji prediksi, melakukan dan mencatat pengamatan serta ide-ide melalui kegiatan. Pada tahap Explanation, guru harus mendorong siswa untuk menjelaskan konsep dengan kalimat mereka sendiri, meminta bukti dan klarifikasi dari penjelasan mereka, dan mengarahkan kegiatan diskusi. Tahap Elaboration, siswa menerapkan konsep dan keterampilan dalam situasi baru melalui kegiatan-kegiatan seperti praktikum. Pada tahap Evaluation dilakukan evaluasi terhadap efektifitas tahap-tahap sebelumnya dan juga evaluasi terhadap pengetahuan, pemahaman konsep yang kadang-kadang mendorong pebelajar melakukan investigasi lebih lanjut.

Berdasarkan tahapan dalam metode pembelajaran inkuiri model the $5 E$ Learning Cycle tersebut, diharapkan siswa tidak hanya mendengar keterangan guru tetapi dapat berperan aktif untuk menggali dan memperkaya pemahaman mereka terhadap konsep-konsep yang dipelajari, misalnya pada materi pokok kalor merupakan salah satu bahan kajian sains fisika kelas VII semester genap siswa SMP atau sederajat. Materi pokok kalor yang dipelajari dalam hal ini adalah (1) Pengearuh kalor terhadap lamanya waktu, (2) kalor menyebabkan perubahan suhu benda, (3) kalor menyebabkan perubahan wujud benda, (4) Penghantar kalor melalui koduksi, (5) Penghantar kalor melalui konveksi dan Penghantar kalor melalui radiasi.

SMP Negeri 1 Singosari merupakan salah satu SMP RSBI di Kabupaten Malang berupaya membelajarkan siswa dengan aktif sehingga diharapkan mendapatkan hasil pembelajaran yang memuaskan dan mampu bersaing di dunia Internasioanal. Oleh karena itu guru harus mampu menggunakan suatu metode pembelajaran yang menarik kepada siswa, sehingga mampu membuat siswa untuk terlibat aktif dalam pembelajaran baik di kelas maupun di lingkungannya. Peran guru dalam pembelajaran Inkuiri dengan model The 5E Learning Cycle adalah mengarahkan dan membimbing siswa untuk menemukan konsep dari pembelajaran dan menganalisanya lebih lanjut (Rustaman, Arifin, \& Permanasari, 2007). Berdasarkan uraian tersebut dilakukan usaha untuk memadukan kelebihan-kelebihan pembelajaran inkuiri dengan model the $5 E$ Learning Cycle khususnyasiswa kelas VII-E SMP Negeri 1 Singosari Kabupaten Malang.

Berdasarkan latar belakang tersebut, maka masalah yang diangkat pada penelitian ini adalah sebagai berikut: (1) Apakah penerapan pembelajaran inkuiri dengan model The $5 E$ Learning Cycle dapat meningkatkan keaktifan belajar siswa kelas VII-E SMP Negeri Singosari Kabupaten Malang?. (2) Apakah penerapan pembelajaran Inkuiri dengan model The 5E Learning Cycle dapat meningkatkan hasil belajar siswa kelas VII-E SMP Negeri 1 Singosari Kabupaten Malang?

Tujuan penelitian ini adalah (1) Meningkatkan keaktifan belajar siswa kelas VII-E SMP Negeri 1 Singosari dengan menerapkan pembelajaran Inkuiri dengan model The 5E Learning Cycle. (2) Meningkatkan hasil belajar IPA siswa kelas VII-E SMP Negeri 1 Singosari dengan menerapkan pembelajaran Inkuiri dengan model The 5E Learning Cycle. 


\section{METODE}

Penelitian ini merupakan jenis Penelitian Tindakan Kelas (PTK) yaitu penelitian yang bertujuan untuk memperbaiki suatu keadaan pembelajaran di kelas dengan melakukan tindakan yang difokuskan pada masalah-masalah dalam kelas atau sekolah, dimana guru terlibat secara penuh perencanaan, aksi atau tindakan, dan refleksi. Dalam penelitian ini menggunakan dua siklus, tiap siklus terdiri dari tiga pertemuan Penelitian Tindakan Kelas ini disesuaikan dengan perubahan yang ingin dicapai yaitu peningkatan terhadap keaktifan belajar siswa dan peningkatan hasil belajar siswa. Menurut (Susilo, Chotimah, \& Sari, 2011), tujuan PTK adalah untuk memperbaiki dan meningkatkan mutu pembelajaran melalui teknik-teknik pengajaran sesuai dengan masalah dan tingkat perkembangan peserta didik, meningkatkan mutu pendidikan, dan meningkatkan keterampilan.

Menurut (Arikunto \& Suharsimi, 2012) menjelaskan bahwa PTK adalah penelititian yang dilakukan oleh guru ke kelas atau disekolah di sekolah tempat mengajar dengan menekankan pada penyempurnaan atau peningkatan proses dan praktik pembelajaran yang secara garis besar terdapat empat tahapan yang lazim, yaitu Planning (Rencana), Action (pelaksanaan), Observation (Pengamatan), dan Reflection (Refleksi).

Sumber data pada penelitian ini adalah (1) Siswa, data yang diperoleh dari siswa adalah data keterlaksanaan pembelajaran Inkuiri dengan The 5E Learning Cycle Model oleh siswa, (2) Guru, data yang diperoleh dari guru adalah data keterlaksanaan pembelajaran Inkuiri dengan The 5E Learning Cycle Model oleh guru, (3) Data keterlaksanaan keaktifan belajar, (4) Data Ketercapaian keterampilan belajar, (5) Data ketercapaian aspek Psikomotorik Siswa, dan (6) Data ketercapaian aspek kognitif siswa yang diperoleh dari hasil tes akhir siklus.

Instrumen pembelajaran terdiri atas rencana pelaksanaan pembelajaran (RPP), lembar observasi keterlaksanaan pembelajaran, Lembar Kerja Siswa (LKS) dan catatan lapangan. RPP materi kalor dibuat untuk tiap-tiap subpokok bahasan, sedangkan LKS yang digunakan selama proses pembelajaran terdiri dari langkah-langkah yang akan dilakukan siswa pada saat kegiatan percobaan.

Instrumen perangkat pembelajaran terdiri atas rencana pelaksanaan pembelajaran (RPP), Lembar observasi keterlaksanaan pembelajaran, Lembar Kerja Siswa (LKS) dan catatan lapangan. RPP materi kalor dibuat untuk tiap-tiap subpokok bahasan, sedangkan LKS yang digunakan selama proses pembelajaran terdiri dari langkah-langkah yang akan dilakukan siswa pada saat kegiatan percobaan.

Instrumen pengukuran ini terdiri dari (1) Tes tertulis dilakukan pada setiap akhir siklus belajar yaitu berupa soal obyektif. Tes digunakan untuk mengetahui tingkat ranah kognitif siswa sebagai penerapan pembelajaran terhadap hasil belajar siswa, (2) Angket, tentang persepsi siswa terhadap pembelajaran Inkuiri dengan model The 5E Learning Cycle diberikan kepada siswa di awal pembelajaran pada siklus I dan akhir pembelajaran pada siklus II. Angket yang digunakan diadopsi dari (Matondang, 2009).

Prosedur pengumpulan data menggunakan skala Likert yang mengubah data menjadi data interval yang terdiri dari 4 kategori yaitu sangat setuju, setuju, tidak setuju, dan sangat tidak setuju. Skor 4 kategori sangat setuju, skor 3 untuk kategori setuju, skor 2 untuk kategori tidak setuju, dan skor 1 untuk kategori sangat tidak setuju. Kisi-kisi pada angket persepsi pada penelitian ini antara lain tumbuhnya keaktifan siswa dalam belajar, meningkatnya rasa percaya diri, siswa merasa senang, dan diskusi. (3) Lembar Observasi Keaktifan Belajar Siswa, dalam penelitian ini observasi keaktifan belajar siswa dilakukan selama proses pembelajaran berlangsung yang disajikan berupa lembar observasi tentang pembelajaran oleh guru fisika dan lembar observasi keterlaksanaan pembelajaran berbasis Inkuiri dengan model The5E Learning Cycle. Data hasil observasi dicatat dalam lembar observasi dan digunakan sebagai data yang menggambarkan berlangsungnya kegiatan pembelajaran.

Data keterampilan belajar meliputi keberhasilan siswa atas kemampuannya dalam memiliki keterampilan pembelajaran yang baik dengan beberapa indikator sudah ditentukan yaitu (1) Siswa berani bertanya/menjawab secara aktif, akan muncul hasil penilaian tidak pernah, jarang, seringkali, dan selalu (2) siswa mampu kerjasama dalam kelompok, akan mendapatakan penilaian yang terdiri dari 4 kategori yaitu tidak mampu, kurang mampu, cukup mampu, dan sangat mampu. (3) Siswa aktif dalam melakukan percobaan, akan mendapatkan penilaian tidak aktif, kurang aktif, aktif, dan sangat aktif. (4) Siswa selalu tepat mengumpulkan tugas yang diberikan guru, akan mendapatkan penilaian tidak tepat, kurang tepat, tepat, dan sangat tepat. (5) Siswa selalu memelihara peralatan laboratorium akan mendapatkan penilaian tidak rapi, rapi tapi tidak bersih, rapi dan bersih, sangat rapih dan bersih. 
Pada aspek Psikomotorik adalah suatu aspek yang dikatakan berhasil apabila siswa mampu mencapai empat tingkatan dalam pembelajarannya, yaitu 1) ketepatan memilih alat ukur,dengan kategori tidak mampu, kurang mampu, mampu, sangat mampu, 2) Kemampuan mengoperasikan alat ukur, dengan kategori tidak tepat, kurang tepat, tepat, sangat tepat, 3) Kemampuan menghitung data, dengan kategori tidak mampu, kurang mampu, mampu, sangat mampu, 4) Ketepatan memasukan data, dengan kategori tidak tepat, kurang tepat, tepat, sangat tepat.

\section{HASIL}

\section{Siklus I}

Tahap perencanaan disusun dalam bentuk langkah-langkah perencanaan yaitu mempersiapkan tindakan, melaksanakan tindakan, observasi untuk memperoleh data, dan merefleksi untuk memperbaiki kelemahan yang terjadi. Pada perencanaan ini, pembelajaran dilakukan dengan pembelajaran inkuiri dengan model the 5E Learning Cycle. Pada siklus I ini terdiri dari tiga kali pertemuan. Pokok bahasan pada siklus I adalah Pengaruh kalor terhadap waktu pada pertemuan ke 1, sub pokok bahasan Pengaruh kalor terhadap massa pada pertemuan ke 2 dan Pengaruh kalor terhadap wujud zat pada pertemuan ke 3. Pelaksana pembelajaran adalah peneliti. Pembelajaran dilaksanakan di ruang laboratorium IPA dan ruang kelas VII-E SMP Negeri 1 Singosari Kabupaten Malang.

Pada tahap perencanaan dilakukan penyusunan perangkat pembelajaran yaitu RPP, LKS, lembar observasi keterlaksanaan tahap pembelajaran inkuiri dengan model the 5E Learning Cycle oleh guru, lembar observasi keterlaksanaan tahap pembelajaran inkuiri dengan the $5 \mathrm{E}$ Learning Cycle oleh siswa, lembar observasi keaktifan belajar, tes hasil belajar kognitif, lembar observasi keterampilan belajar, dan lembar aspek psikomotorik.

Pada siklus I dilaksanakan tahap-tahap pembelajaran siklus belajar model lima tahap (The 5E Learning Cycle) guru dan siswa belum terbiasa dengan pembelajaran ini. Siswa belum mampu melakukan percobaan dengan baik sehingga waktu yang diperlukan menjadi lebih lama daripada waktu yang dialokasikan. Siswa masih melakukan percobaan dengan bantuan LKS dan dalam mempresentasikan hasilnya masih sering meminta bantuan guru bila ada pertanyaan yang sulit.

Lembar kerja siswa (LKS) pada siklus I masih belum mampu memberikan petunjuk yang cukup jelas kepada siswa untuk melakukan percobaan sesuai dengan prosedur yang diharapkan. Semua kelompok masih sering bertanya kepada guru tentang langkah-langkah untuk melakukan percobaan. Siswa masih salah merangkai alat, membaca thermometer, dan mengukur massa es.

Pada pertemuan I siswa belum memberikan pertanyaan atau tanggapan terhadap siswa lain yang sedang presentasi dan sibuk mempersiapkan presentasi kelompok masing-masing. Tahap evaluasi tidak dapat terlaksana karena waktu pembelajaran telah habis. Kemampuan kognitif siswa masih kurang baik karena masih lebih rendah dari criteria yang ditetapkan. Hal ini dapat diketahui dari hasil tes belajar kognitif siklus I hanya Kemampuan kognitif pada siklus I sebesar 33,33\% sehingga ketuntasan belajar masih 64,51\%.

\section{Siklus II}

Siklus II terdiri dari tiga kali pertemuan. Sub pokok bahasan adalah Kalor merambat melalui konduksi pada pertemuan ke 1, Kalor merambat melalui konveksi pada pertemuan ke 2, dan kalor merambat melalui Radiasi pada pertemuan ke 3. Berdasarkan kelemahan pada siklus I, maka pada siklus IIdilakukan perbaikan sebagai berikut: (1) Pada siklus II guru lebih memperhatikan waktu sehingga 5 tahap dapat terlaksana dengan baik. (2) Sebelum percobaan guru memberikan pengarahan terlebih dahulu. (3) Siswa disarakan tidak sering mengacu pada LKS tetapi membuat laporan hasil percobaan. (4) Siswa diharapkan mempresentasikan hasil percobaannya dengan lebih baik. (5) Siswa dapat membuat kesimpulan dan menjawab permasalahan dari teman-temannya secara baik dan benar.

Pada siklus II Lima tahap dapat terlaksana dengan baik, dimana guru dan siswa sudah terbiasa dengan pembelajaran inkuiri dengan model the 5E Learning Cycle. Siswa sudah diberi kebebasan melaksanakan pembelajaran dengan caranya sendiri tanpa bantuan LKS dan siswa sudah mampu mengalokasikan waktu dengan baik. Pada saat presentasi siswa aktif menggunakan pembelajaran dengan bantuan Power point untuk menampilkan hasil percobaannya. 
Berdasarkan hasil pengamatan selama dua siklus I dan siklus II diperoleh hasil analisis data yang menunjukkan bahwa terjadi peningkatan keaktifan belajar siswa pada siklus pertama adalah $24,4 \%$. Rerata tertinggi untuk indikator tertentu pada indikator keberanian bertanya sebesar $1,4 \%$ dan rerata terendah pada indikator mempertanyakan gagasan yaitu hanya $0,2 \%$. Sedangkan pada siklus kedua terjadi peningkatan adalah $37,3 \%$, lebih meningkat dibandingkan pada siklus pertama. Sedangkan rerata tertinggi sebesar $2,3 \%$ adalah pada indikator keberanian dan indikator terendah mempertanyakan gagasan orang lain yaitu $0,3 \%$, hasil selengkapnya dapat dilihat pada Gbr 1.

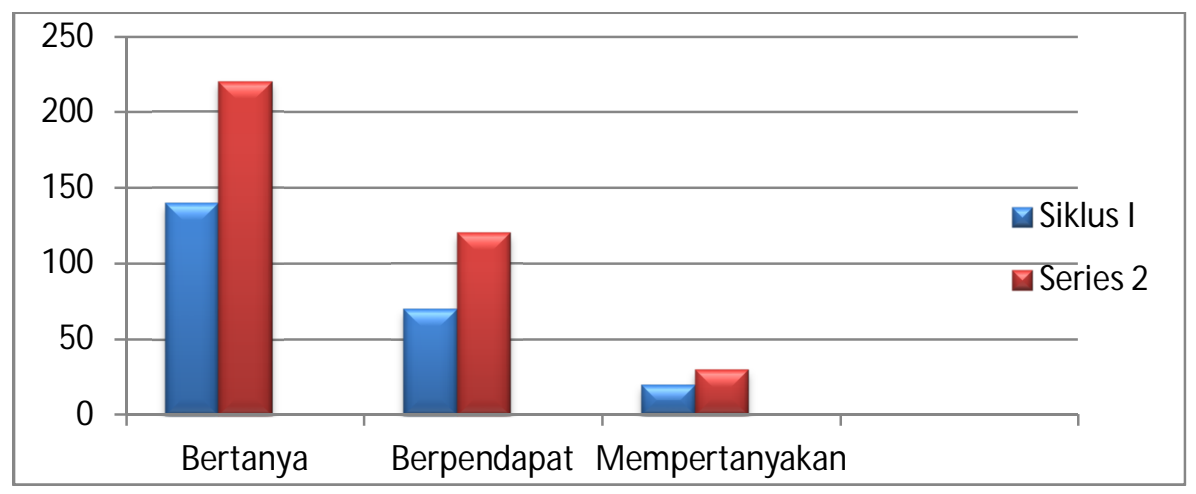

Gambar 1. Grafik Peningkatan Keaktifan belajar Siswa

Pada Gbr 1 menunjukan peningkatan keaktifan siswa dalam belajar saat pembelajaran inkuiri dengan model lima tahap (The 5E Learning Cycle). Keterlaksanaan pembelajaran inkuri dengan moedel lima (The $5 E$ Learning Cycle) oleh guru mengalami peningkatan dari siklus I ke II seperti pada Gbr 2.

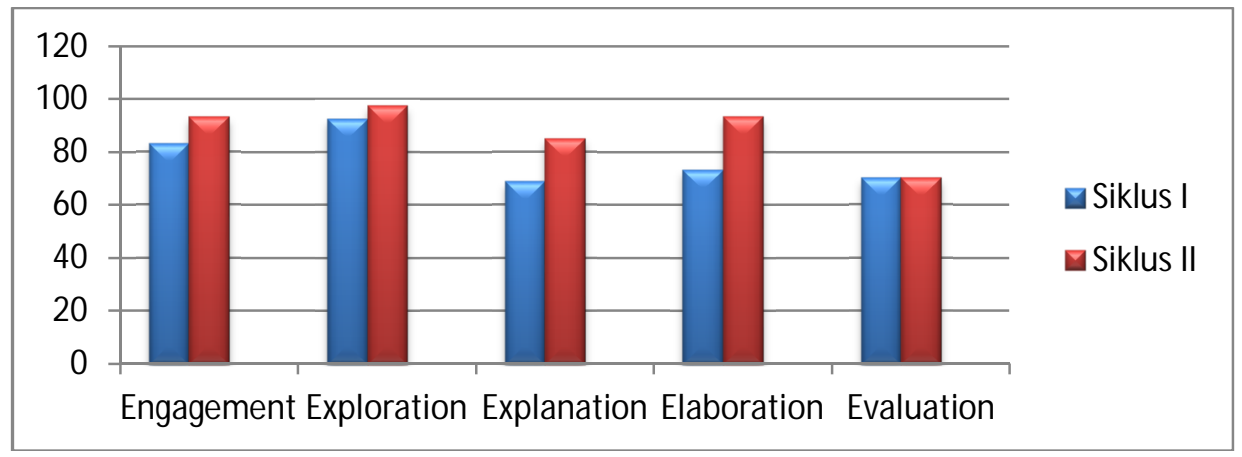

Gambar 2. Keterlaksanaan Tahap Pembelajaran Inkuiri dengan Model The 5E Learning Cycle oleh Guru

Sedangkan keterlaksanaan oleh siswa pada pembelajaran Inkuiri dengan model siklus belajar lima tahap (The 5E Learning Cycle) oleh siswa pada siklus I dan siklus II dapat di lihat pada Gbr 3. 


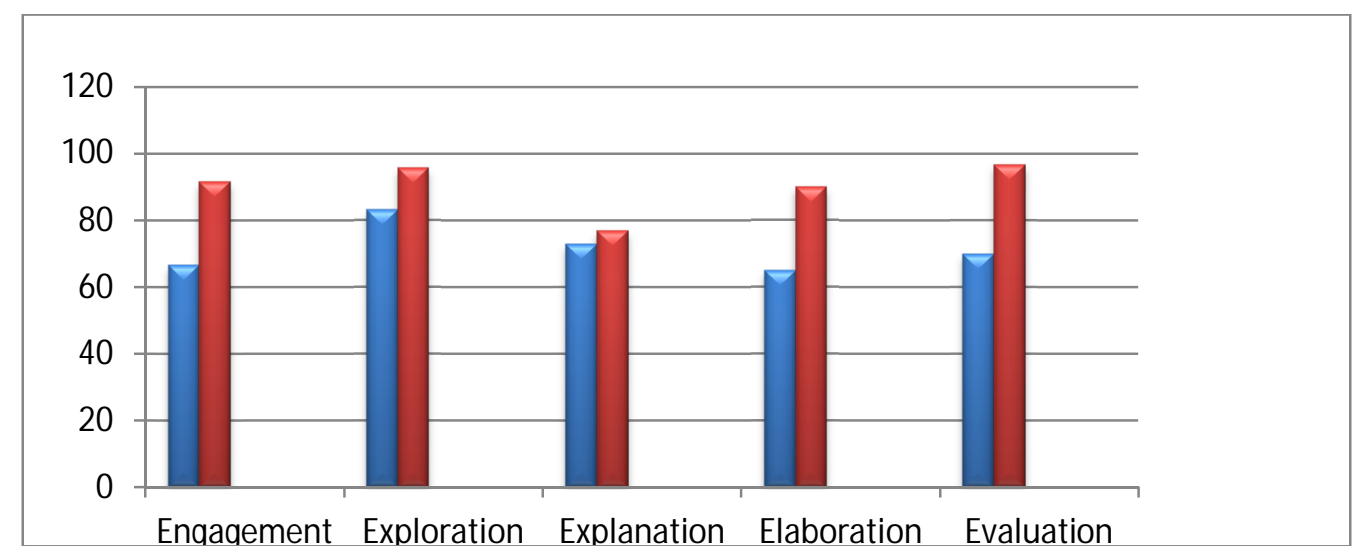

Gambar 3. Keterlaksanaan Tahap Pembelajaran Inkuiri dengan Model the 5E Learning Cycle oleh Siswa

Ketercapaian keterampilan belajar dari siklus I ke siklus II mengalami peningkatan pada setiap indikatornya. Data selengkapnya tersaji pada Gbr 4. Data ketercapaian aspek psikomotorik siswa mengalami peningkatan dari siklus I ke siklus II seperti pada Gbr 5.

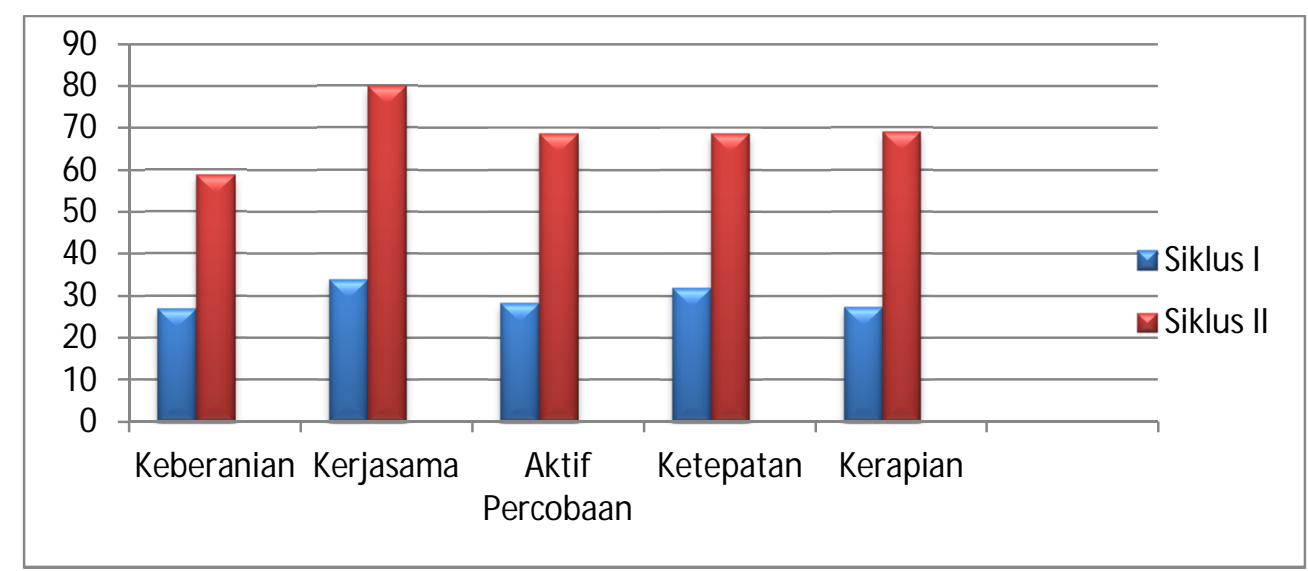

Gambar 4. Ketercapaian Keterampilan Belajar Siswa Siklus I dan Siklus II

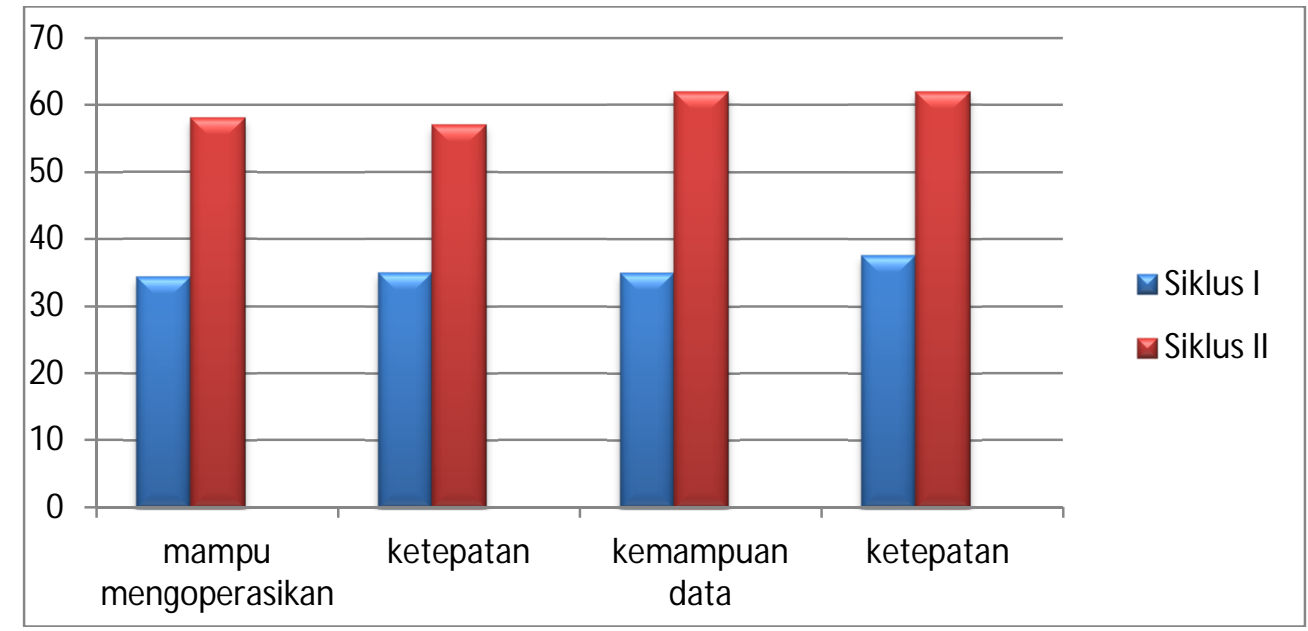

Gambar 5. Ketercapaian Aspek Psikomotorik dari Siklus I ke Siklus II 
Pada aspek kognitif juga terjadi peningkatan hasil belajar siswa dari siklus pertama dan siklus kedua sebesar $8,33 \%$. Hal tersebut menunjukkan bahwa penerapan pembelajaran Inkuiri dengan model the $5 E$ Learning Cycle mampu meningkatkan keaktifan siswa dalam pembelajaran inkuiri dengan model silklus belajar lima tahap sehingga siswa mampu mencapai tingkatan kognitif lebih tinggi hingga ke tingkatan analisis.

Pada siklus pertama nilai dibawah KKM sebanyak 11 siswa dapat teratasi pada siklus ke II dengan sampai pada C4 dan semua siswa tuntas. Dan peningkatan hasil belajar aspek kognitif pada siklus I dan siklus II dapat dilihat pada Gbr 6. Dari Gbr 6 terlihat jelas ada peningkatan hasil tes kognitif belajar siswa sebesar $8,33 \%$. Hal ini menunjukan siswa sangat menguasai pembelajaran inkuiri dengan model lima tahap ini.

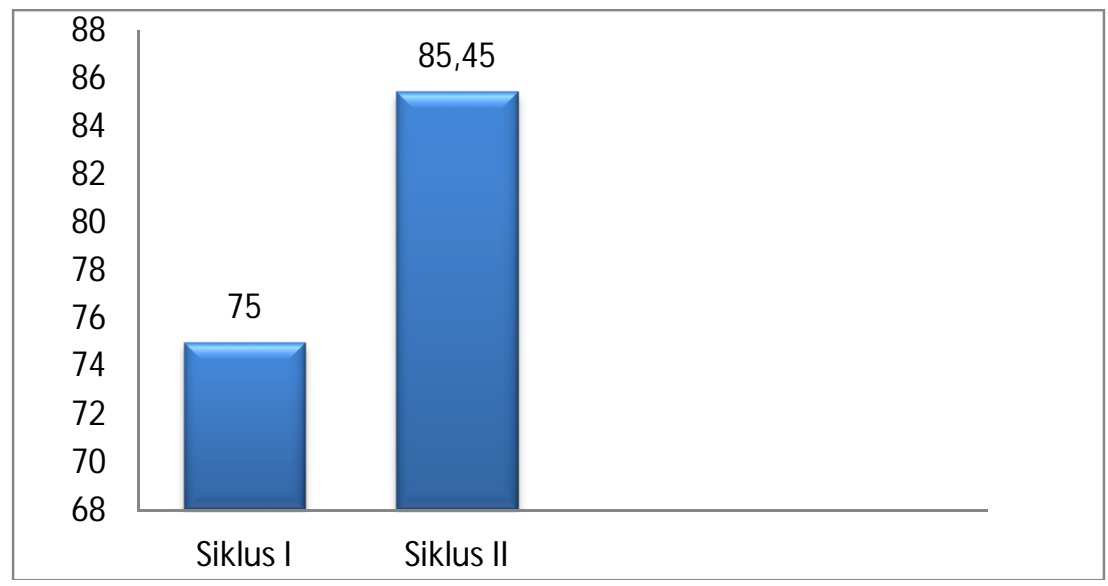

Gambar 6. Peningkatan Hasil Belajar pada Aspek Kognitif

\section{PEMBAHASAN}

Hasil pengamatan yang didapat pada siklus I, menunjukan nahwa pada siklus I khusunya pada pertemuan 1 tidak semua tahap pembelajaran terlaksanakan yaitu tahap Evaluation, penyebabnya siswa belum mampu melaksanakan percobaan dengan baik. Siswa masih salah dalam menganalisis dan mengambil kesimpulan.Siswa tidak diberi kebebasan untuk melaksanakan percobaan dengan cara mereka sendiri, karena siswa masih melaksanakan percobaan sesuai dengan LKS. Guru diharapkan lebih memperhatikan alokasi waktu sehingga semua tahap pembelajaran dapat terlaksanakan dengan optimal.

Pada siklus II tahap-tahap pembelajarn dapat terlaksana dengan baik, karena guru bisa membagi alokasi waktu pembelajaran. Siswa diberi kebebasan melaksanakan percobaan dengan caranya sendiri tanpa bantuan LKS , hal ini dapat dilihat pada tahap Exploration. Selama kegiatan guru membimbing siswa dengan baik. Hasil percobaan kemudian dipresentasikan oleh siswa didepan kelas. Guru juga mengklarifikasi terhadap jawaban siswa yang kurang tepat, sehingga siswa dapat lebih mudah dalam menyimpulkan hasil pembelajaran. Pada tahap Elaboration berlangsung dengan baik, dimana guru memberikan permasalahan berupa pertanyaan yang berkaitan dengan penerapan konsep, akibatnya siswa dapat menerapkan konsep baru dalam kehidupannya. Pada tahap Evaluation, guru dan siswa dapat menyimpulkan seluruh hasil pembelajaran dengan baik, sehingga membantu pemahaman siswa.

Peningkatan pembelajaran dari siklus I ke siklus II terjadi pada semua tahap pembelajaran yaitu sebesar 14,05 \%, karena kelamahan pada pembelajaran inkuiri akan tertutupi oleh pembelajaran model The $5 E$ Learning Cycle, sehingga siswa dapat bertanya maupun menjawab berdasarkan tahapan siklus belajar. Siswa aktif menjawab berbagai pertanyaan melalui percobaan yang dilaksanakan tanpa harus dipandu oleh LKS

\section{Meningkatkan Keaktifan Belajar siswa}

IPA berkaitan dengan cara mencari tahu tentang alam secara sistematis, bukan hanya sebagai penguasaan kumpulan pengetahuan yang beripa fakta-fakta, konsep-konsep atau prinsip-prinsip saja, tetapi juga merupakan suatu proses penemuan. IPA menekankan pada pemberian pengalaman langsung untuk mengembangkan kompetensi agar siswa menjelajahi dan memahami alam sekitar secara ilmiah (Depdiknas, 2006). Keaktifan belajar yang diharapkan dalam penelitian ini siswa mampu menerapkan pembelajaran 
inkuiri dengan model siklus pembelajaran lima tahap untuk mengembangkan kompetensi belajar IPA agar siswa memahami alam sekitar.

Pengamatan yang dilakukan guru adalah memiliki permasalahan dengan kurang keaktifan siswa dikelas saat pembelajaran berlangsung. Hal ini terlihat pada saat diadakan pembelajaran di laboratorium tentang materi kalor terlihat keaktifan siswa sangat kurang dan pada saat diadakan presentasi hasil percobaan siswa banyak yang kurang aktif dalam menjawab pertanyaan, memberikan gagasan dari teman yang melakukan presentasi dan hanya beberapa siswa saja yang mampu menjawab.

Terlaksananya kegiatan pembelajaran inkuiri dengan model The 5E Learning Cycle berlangsung, siswa terlihat senang. Mereka merasa santai dan enjoy dalam melakukan tahapan-tahapan percobaan sesuai siklus belajar lima tahap, dan mereka bisa mengemukakan ide, gagasan ataupun menjawab pertanyaan-pertanyaan dari teman-temannya. Suasananya menyenangkan meskipun terkadang terlihat siswa yang agak tergopohgopoh karena tidak bisa menjawab pertanyaan. Lokasi pembelajaran di ruang laboratorium IPA (Fisika) SMP Negeri 1 Singosari yang memungkinkan siswa tidak tegang karena peralatan tersedia secara langsung dan cukup menunjang pembelajaran. Bahkan sesekali siswa tersenyum menunjukkan bahwa siswa dapat menyelesaikan percobaan dan presentasi di depan dengan baik.

Dimana pada siklus I bahwa rerata pencapaian ketiga indikator untuk semua siswa pada siklus pertama adalah $24,4 \%$ dan terjadi peningkatan pada siklus ke II sebesar 37,3\%. Sedangkan rerata tertinggi adalah pada indikator keberanian bertanya yaitu pada siklus I sebesar 1,4\% meningkat di siklus II menjadi $2,2 \%$, rerata keberanian berpendapat pada siklus I sebesar 0,7\% menjadi meningkat di siklus II sebesar 1,2\% dan rerata terendah adalah indikator mempertanyakan gagasan orang lain yaitu hanya $0,2 \%$ di siklus I menjadi meningkat di Siklus II sebesar 0,3\%. Dari pembahasan diatas, dapat disimpulkan bahwa dengan pembelajaran inkuiri model siklus belajar lima tahap terjadi persentase peningkatan sebesar $53 \%$.

Ketika pembahasan hasil uji kompetensi, tampak sebagian besar siswa aktif mengangkat tangan pertanda mereka siap untuk menjawab pertanyaan. Mereka terlihat senang dan selalu berupaya untuk ditunjuk menjawab pertanyaan yang dibacakan guru. (Capacchione, 1989) berpendapat bahwa murid-murid yang mengikuti pembelajaran secara aktif mendapatkan nilai yang lebih baik, lebih banyak berpartisipasi, dan merasa lebih bangga akan diri sendiri. Selain itu, ketika ada jawaban temannya yang kurang tepat mereka berebut untuk memberikan jawaban dan argumentasinya. Hal ini menunjukkan bahwa mereka merasa senang dengan kegiatan pembelajaran tersebut.

Berdasarkan hasil wawancara dengan beberapa siswa dan kesan-kesan yang ditulis mereka tentang pembelajaran yang dilakukan menyatakan bahwa mereka menyenangi strategi pembelajaran ini karena siswa secara aktif melakukan kegiatan praktikum, berdiskusi, dan mengemukakan pendapat baik di dalam diskusi kelompok maupun di forum diskusi kelas. Hambatan yang mereka rasakan saat pembelajaran ini adalah terbatasnya waktu, sehingga tidak adanya kesempatan bertanya ketika diskusi kelas akibat di dominasi dari kelompok siswa pandai yang aktif bertanya.

Menurut (Sunarto, 2007) guru harus dapat menyediakan banyak kesempatan bagi siswa lambat yang tidak dapat dengan mudah memahami isi suatu pembelajaran untuk berkomunikasi dengan kelompok pandai. Oleh karena itu guru harus mengelola pembelajaran dengan baik, sehingga masing-masing siswa memiliki keaktifan dalam pembelajarannya. Jika siswa sudah aktif dalam pembelajaran, maka siswa tidak akan mengantuk selama pembelajaran dan mereka terdorong tuntuk mempelajari meteri bahan ajar yang akan dikaji, agar mereka secara aktif dapat menjawab pertanyaan guru dan teman sejawatnya saat diskusi. Hal tersebut menunjukkan terjadi perilaku positif pada siswa terhadap pembelajaran dengan menggunakan strategi pembelajaran inkuiri dengan model The $5 E$ Learning Cycle.

\section{Hasil Belajar}

Menurut Taksonomi Bloom (Muslihati, 2005) membagi hasil belajar dalam tiga aspek yaitu: aspek kognitif, keterampilan belajar, dan aspek psikomotorik. Berdasarkan hasil pengamatan yang dilakukan peneliti pada pembelajaran inkuiri dengan model siklus belajar lima tahap telah mampu meningkat hasil belajar siswa kelas VII-E SMP Negeri 1 Singosari Malang. 
Data untuk setiap aspeknya dapat dilihat sebagal berikut.

\section{Aspek Kognitif}

(Anderson \& Krathwohl, 2001) melakukan revisi terhadap enam jenjang kemampuan kognitif yang diungkapkan oleh Bloom tersebut. Keenam jenjang kognitif tersebut adalah sebagai berikut.

a. Mengingat (remember)

Mengingat merupakan kemampuan seseorang untuk mengingat-ingat kembali (recall) atau mengenali kembali tentang suatu istilah, konsep, hukum, rumus dan sebagainya. Mengingat sesuatu tersebut tidak bermaksud untuk digunakan. Mengingat merupakan jenjang kemampuan berpikir paling rendah.

b. Memahami (understand)

Memahami merupakan kemampuan seseorang mengetahui sesuatu hal dari berbagai segi. Seorang siswa dikatakan memahami sesuatu hal, apabila ia dapat memberikan penjelasan atau menguraikan dengan menggunakan kata-katanya sendiri. Memahami termasuk jenjang kemampuan berpikir setingkat lebih tinggi dari mengingat.

c. Menerapkan (apply)

Menerapkan merupakan kesanggupan seseorang untuk menerapkan/ menggunakan suatu prinsip-prinsip, teori-teori, rumus-rumus dan sebagainya dalam situasi baru dan nyata. Menerapkan termasuk jenjang kemampuan berpikir setingkat lebih tinggi dari memahami.

d. Menganalisis (analyze)

Menganalisis merupakan kemampuan seseorang untuk menguraikan suatu bahan/keadaan menjadi bagian-bagian yang lebih kecil dan mampu memahami hubungan diantara bagian-bagian tersebut. Apabila kemampuan análisis sudah dimiliki seseorang maka orang itu akan mampu mengkreasi sesuatu yang baru. Menganalisis termasuk jenjang kemampuan berpikir setingkat lebih tinggi dari menerapkan.

e. Menilai (evaluate)

Menilai merupakan kemampuan seseorang untuk membuat keputusan/kesimpulan terhadap suatu nilai, kondisi, atau gagasan. Contoh: Apabila seseorang siswa dihadapkan pada beberapa pilihan, maka ia akan mampu memilih satu pilihan yang terbaik sesuai dengan kriteria/standart yang berlaku. Menilai termasuk jenjang kemampuan berpikir setingkat lebih tinggi dari jenjang menganalisis.

f. Berkreasi (create)

Berkreasi merupakan kemampuan seseorang untuk memadukan unsur-unsur/bagian-bagian secara logis, sehingga menjelma menjadi suatu formula/pola baru, termasuk jenjang kemampuan berpikir paling tinggi dalam aspek kognitif.

Kedua kemampuan berpikir pertama disebut jenjang kognitif tingkat rendah dan keempat kemampuan berpikir selanjutnya termasuk jenjang kognitif tingkat tinggi. Keenam jenjang kognitif tersebut selanjutnya lebih dikenal dengan revisi taxonomi Bloom.

Penilaian ranah kognitif diperoleh dari skor tes akhir tindakan siklus I dan skor tes akhir tindakan siklus II. Kemampuan kognitif pada siklus I sebesar 33,33\%. Ketercapaian terendah pada tingkat kognitif C1 sebesar $20 \%$. Ketercapaian pada tingkat kognitif C2 sebesar $40 \%$ sama dengan pada nilai ketercapain tingkat kognitif C3 sebesar 40\%. Hal ini dapat dilihat dari perolehan hasil ulangan harian pada siklus I rata-rata nilainya 75 sedangkan pada siklus II rata-rata nilainya 85,45 berarti pembelajaran siswa mengalami peningkatan.

Rata-rata skor hasil belajar siswa pada siklus I sebesar 75, sedangkan rata-rata skor hasil belajar siswa pada siklus II sebesar 85,45 dengan begitu secara klasikal siswa telah mencapai ketuntasan belajar dengan kenaikan sebesar 8,33\% karena siswa telah mencapai skor $>75$ yaitu Kriteria Ketuntasan Minimal (KKM) nilai mata pelajaran fisika yang ditetapkan oleh pihak sekolah SMP Negeri 1 Singosari Malang. Hal ini menunjukkan bahwa model pembelajaran Inkuiri dengan model siklus belajar lima tahap (The 5E Learning Cycle) yang telah diterapkan oleh peneliti dapat meningkatkan hasil belajar siswa.

Tipe soal tes akhir masing-masing siklus adalah sama, yaitu soal pilihan ganda. Adapun kategori tingkatan kognitif pada siklus II adalah antara C1 (pengetahuan) sampai C4 (analisis). Pada siklus I perbandingan jumlah soalnya adalah sebagai berikut, untuk C1 sebanyak 2 soal, C2 sebanyak 4 soal, dan C3 sebanyak 4 soal. Sedangkan pada siklus II perbandingan jumlah soalnya adalah sebagai berikut, untuk C1 sebanyak 5 soal, C2 sebanyak 6 soal C3 sebanyak 4 dan C4 sebanyak 5 soal. 
Pada siklus II peneliti memperbanyak soal tingkat kognitif C3 dan ternyata hasilnya menunjukkan suatu peningkatan. Sebagian besar siswa mampu menyelesaikan soal tersebut. Peneliti hanya ingin mengetahui peningkatan keaktifan belajar siswa dalam menganalisis soal setelah penerapan pembelajaran Inkuiri dengan model siklus belajar Lima tahap (The $5 E$ Learning Cycle).

Pada siklus I diperoleh $40 \%$ siswa sudah mampu mencapai tingkatan kognitif penerapan (C3), namun pada siklus II siswa sudah mampu sampai pada tingkatan analisis (C4), hal ini menunjukan peningkatan belajar yang lebih baik dari pada di siklus I. Peningkatan tersebut cukup signifikan mengingat jumlah soal dengan tingkatan aplikasi (C3) pada siklus II lebih banyak jika dibandingkan dengan siklus I. Oleh karena itu peningkatan tersebut yang cukup besar pada siklus I maupun siklus II, hal tersebut menunjukkan bahwa penerapan pembelajaran Inkuiri dengan model The $5 E$ Learning Cycle mampu meningkatkan keaktifan siswa dalam pembelajaran inkuiri dengan model silklus belajar lima tahap sehingga siswa mampu mencapai tingkatan kognitif lebih tinggi hingga ke tingkatan analisis.

Keberhasilan ini sesuai dengan pernyataan (Hasibuan, 2005), siswa tidak cukup hanya dituntut untuk mengingat kembali suatu informasi dan mengemukakannya dengan kata-kata sendiri, namun siswa perlu diminta untuk mengaplikasikan suatu informasi yang telah dipelajarinya dengan penuh aktif. Pertanyaan yang menuntut siswa untuk mengaplikasikan suatu informasi yang telah dipelajari dikenal dengan pertanyaan aplikasi. Pertanyaan aplikasi menuntut siswa untuk mengaplikasikan suatu aturan, hukum atau prinsip dalam situasi bawahan tunggal yang benar dari masalah itu.

Proses pembelajaran bukan lagi sekedar transfer pengetahuan dari guru ke siswa, seperti dalam falsafah behaviorisme, dan tetapi merupakan proses pemerolehan konsep yang berorientasi pada keterlibatan siswa secara aktif dan langsung dalam pembelajaran. Pembelajaran akan lebih bermakna dan menjadikan skema dalam diri siswa menjadi pengetahuan fungsional yang setiap saat diorganisasi oleh siswa untuk menyelesaikan masalah-masalah yang dihadapi. Penerapan pembelajaran inkuiri dengan model siklus belajar lima tahap di dalamnya terdapat pembentukan pemahaman atau aspek kognitif. Oleh karena itu peningkatan keaktifan belajar siswa juga dapat meningkatkan hasil belajar kognitif siswa.

\section{Aspek Keterampilan belajar}

Pada aspek keterampilan belajar yang ditekankan adalah keberanian bertanya, kerjasama dalam kelompok, keaktifan dalam percobaan, ketepatan mengumpulkan laporan, dan keaktifan dalam melakukan percobaan. Pada penerapan pembelajaran inkuiri dengan model siklus belajar lima tahap ini ternyata dapat meningkatkan aspek keterampilan belajar siswa, hal ini dapat terlihat dari kenaikan presentase rerata yaitu $29,80 \%$ pada siklus I meningkat menjadi $59,20 \%$ pada siklus II.

\section{Aspek Psikomotorik}

Pembelajaran inkuiri dengan model siklus belajar lima tahap juga mengalami peningkatan pada aspek psikomotorik siswa. Hal ini dapat dilihat dari antusiasnya siswa dalam melakukan percobaan. Selama kegiatan percobaan pada siklus I, siswa masih mengalami kesulitan dalam mengoperasikan alat karena siswa belum paham dengan cara penggunaan alat-alat dalam percobaan tersebut.

Pada siklus II siswa sudah tidak mengalami kesulitan dalam mengoperasikan alat. Ini disebabkan siswa sudah jelas dalam memahami petunjuk yang ada di LKS. Saat praktikum siswa terlihat aktif dalam melakukan percobaan hal ini mengindikasikan siswa antusias dan menikmati percobaan tersebut, hal ini dapat terlihat dari kenaikan presentase rerata yaitu $34,74 \%$ pada siklus I menjadi $69,06 \%$ pada siklus II.

Keberhasilan ini dapat dikatakan bahwa hasil belajar khususnya ranah psikomotor sudah berhasil tetapi peningkatan pada aspek proses masih belum memenuhi persentase keberhasilan yang ditentukan yaitu sebesar $70 \%$, hal ini terjadi karena keterbatasan waktu. Jadi diharapkan pada guru bidang studi agar lebih menekankan aspek prosesnya dan cara yang bisa dilakukan yaitu dengan mengalokasikan waktu.

\section{SIMPULAN DAN SARAN}

\section{Simpulan}

Berdasarkan hasil analisis dan pembahasan, dapat disimpulkan bahwa, Pembelajaran Inkuiri dengan siklus belajar model The 5E Learning Cycle dapat meningkatkan keaktifan dan hasil belajar siswa IPA siswa kelas VII-E SMP Negeri 1 Singosari Kabupaten Malang. Peningkatan keaktifan belajar disini adalah dimana siswa bisa berperan secara aktif dalam proses pembelajaran. Keaktifan belajar ini ditandai dengan dengan 
meningkatnya keberanian siswa untuk bertanya, keberanian untuk mengemukakan pendapat dan keberanian mempertanyakan gagasan/ide. Peningkatan ini juga meliputi aspek kognitif, aspek keterampilan belajar, serta aspek psikomotorik siswa. Indikator aspek kognitif adalah hasil rerata tes pada siklus I sebesar 75, mengalami peningkatan sebesar menjadi 85,45, indikator aspek keterampilan belajar ini dapat terlihat dari kenaikan presentase rerata yaitu $60,20 \%$ pada siklus I meningkat menjadi $77,87 \%$ pada siklus II, sedangkan indikator aspek psikomotorik adalah mengalami kenaikan, hal ini dapat dilihat dari siswa antusias dan menikmati percobaan tersebut, dandapt terlihat dari kenaikan presentase rerata yaitu $56,75 \%$ pada siklus I menjadi $73,58 \%$ pada siklus II.

\section{Saran}

Berdasarkan hasil penelitian ini, saran-saran yang dapat diberikan peneliti sebagai berikut: (1) Kepada para guru mata pelajaran fisika, agar mencoba menerapkan pembelajaran Inkuiri dengan model The $5 E$ Learning Cycle sehingga diharapkan dapat meningkatkan keaktifan belajar siswa dan hasil belajar fisika siswa. (2) Kepada pihak sekolah, agar mencoba mengembangkan pembelajaran Inkuiri dengan model The 5E Learning Cycle sebagai upaya pengembangan sekolah, utamanya peningkatan kualitas proses pembelajaran di sekolah. (3) Bagi Peneliti lain, agar menjadikan hasil penelitian ini sebagai bahan referensi untuk melakukan penelitian mengenai pelaksanaan pembelajaran berbasis Inkuiri dengan model The 5E Learning Cycle, sehingga diperoleh hasil yang lebih maksimal lagi.

\section{DAFTAR RUJUKAN}

Anderson, L. W., \& Krathwohl, D. R. (2001). A Taxonomy for Learning, Teaching, and Assessing: A revision of Bloom's Taxonomy of Educational Objectives. New York: Addison Wesley Longman.

Arikunto, A., \& Suharsimi, S. (2012). Dasar-dasar Evaluasi Pendidikan. Jakarta: Bumi Aksara.

Bybee, R. W. (1989). Science and Technology Education for the Elementary Years: Frameworks for Curriculum and Instruction.

Capacchione, L. (1989). The Creative Journal for Children: A Guide for Parents, Teachers, and Counselors.

Dasna, I. W. (2006). Model Siklus Belajar (Learning Cycle) Kajian Teoritis dan Implementasinya dalam Pembelajaran Kimia. IW Dasna, \& Sutrisno, Model-Model Pembelajaran Konstruktivistik Dalam Pembelajaran Sainas-Kimia, 6998.

Depdiknas. (2006). Pedoman Penyusunan Kurikulum Tingkat Satuan Pendidikan Jenjang Pendidikan Dasar dan Menengah.

Hasibuan, S. M. (2005). Organisasi dan motivasi (dasar peningkatan produktivitas). Jakarta: Bumi Aksara.

Matondang, Z. (2009). Validitas dan reliabilitas suatu instrumen penelitian. Jurnal Tabularasa, 6(1), 87-97.

Muslihati, M. (2005). Bahan Ajar Mata Kuliah Dan Pembelajaran. Malang: Lembaga Pengembangan Pendidikan dan Pengembangan Universitas Neibnugeri Malang.

Rustaman, N. Y., Arifin, M., \& Permanasari, A. (2007). Mengefektifkan Pembelajaran Sains dan Animasinya untuk Mengembangkan Kemampuan Dasar Bekerja Ilmiah dengan Berbagai Metode. Laporan Penelitian Hibah Pasca, didanai DP2M Ditjen Dikti.

Sanjaya, W. (2008). Strategi Pembelajaran Berorientasi Standar Proses Pendidikan Jakarta. Jakarta: Kencana Prenada Media.

Sunarto, S. (2007). Perkembangan Peserta Didik. Jakarta: PT Adi Mahasatya Jakarta.

Susilo, H., Chotimah, H., \& Sari, Y. D. (2011). Penelitian Tindakan Kelas. Malang: Bayumedia Publishing.

Wartini, A., Hadi al-asy'ari, M. K., \& Multahada, A. (2018). Menggagas Model Pembelajaran Discovery-Inquiry pada Pendidikan Anak Usia Dini. Intizar, 23(1), 151-164. https://doi.org/10.19109/intizar.v23i1.1614

Yuliati, L. (2008). Model-model Pembelajaran Fisika: Teori dan Praktek. Malang. 